\title{
Production, Trading and Potential Utilization of Fish Scale in Khulna, Bangladesh
}

\section{Muhammad Abdur Rouf ${ }^{1 *}$, Mo Rony Golder ${ }^{1}$, Naima Ahmed Kana ${ }^{1}$, Sudip Debnath ${ }^{1}$, Md. $^{3}$ Moshiur Rahman ${ }^{1}$, Roshmon Thomas Mathew ${ }^{2}$, Yousof Naser Alrashada ${ }^{3}$}

${ }^{1}$ Fisheries and Marine Resource Technology Discipline, Khulna University, Khulna-9208, Bangladesh; ${ }^{2}$ Fish Resources Research Center, King Faisal University, Hofuf-420, Al-Absa, Kingdom of Saudi Arabia; ${ }^{3}$ Department of Animal and Fish Production, College of Agricultural and Food Sciences, King Faisal University, Al-Ahsa, Kingdom of Saudi Arabia.

\begin{abstract}
Fish scales are generally considered as obsolete fish waste in Bangladesh, though they are the valuable component with versatile applications throughout the world. Therefore, this study was conducted to investigate the production, market chain, and future potential of fish scales in Khulna region of Bangladesh following the primary and secondary data. The major fish species contributing scales in the study area are Labio rohita, Lates calcarifer, Catla catla, Cirrbinus cirrbosis, Anabas testudineus, Oreocbromis niloticus, Mugil cephalus, and Labeo bata. The study revealed that only $30 \%$ of fish scales were utilized of which $90 \%$ were exported and $10 \%$ were used in local fish and poultry feed industries. The scales were exported to Japan, Hong Kong, Singapore, Malaysia, Thailand, and China following a simple market chain that includes local fish cutters, scale retailers, national dealers, and finally importers sequentially. The scales' price was varied from 295 to 472 US\$/MT in the local market and 500 to 2000 US\$/MT in the export market following the market availability and size. A huge amount (70\%) of fish scales remains unutilized which could be a potential for better economic growth in Bangladesh. Therefore, initiatives of commercial utilization of fish scales is expected with a sound institutional policy in Bangladesh.
\end{abstract}

Keywords | Fish scale, Price, Market chain, Usage, Bangladesh

Received | July 22, 2021; Accepted | September 25, 2021; Published | November 15, 2021

"Correspondence | Muhammad Abdur Rouf, Fisheries and Marine Resource Technology Discipline, Khulna University, Khulna-9208, Bangladesh; Email: rouf@ fmrt.ku.ac.bd, roufku@yahoo.com

Citation | Rouf MA, Golder MR, Kana NA, Debnath S, Rahman MM,Mathew RT, Alrashada YN (2021). Production, trading and potential utilization of fish scale in Khulna, Bangladesh. Adv. Anim. Vet. Sci. 9(12): 2194-2200.

DOI | http://dx.doi.org/10.17582/journal.aavs/2021/9.12.2194.2200

ISSN (Online) | 2307-8316; ISSN (Print) | 2309-3331

Copyright (C) 2021 Rouf et al. This is an open access article distributed under the Creative Commons Attribution License, which permits unrestricted use, distribution, and reproduction in any medium, provided the original work is properly cited.

\section{INTRODUCTION}

$\mathrm{C}$ onsumption of fish is being increased in greater quantities in the world. Consequently, a huge amount of solid wastes including fish skin, bones, scales, and viscera are being generated in households, fish shops, markets, and processing industries which are together accounted for approximately 50-70\% (Kittiphattanabawon et al., 2005; Wu et al., 2010). These wastes are also considered as pollutants causing a serious impact on the environment (Lopes et al., 2015). A strong off-smell due to improper disposal of these wastes is very common in developing countries which may generate high chemical and biological oxygen demands in the water bodies (Kittiphattanabawon et al., 2005). A few research were conducted to make certain environmentally friendly and profitable options for the utilization of fish processing wastes such as converting them into high-value by-products and value-added fishery products that can be used as fertilizers and animal feed as well as human stuff (Chakraborty et al., 2011; Nagai and Suzuki, 2000; Santana et al., 2019). Such products include bioactive proteins and peptides, omega-3 fatty acids, customized health products, natural pigments, and industrial enzymes, functional poultry and aquaculture 
feed, biodiesel and biogas compositions, organic fertilizer, and compost (Kumari et al., 2017; Nagai and Suzuki, 2000; Sankar et al., 2008).

Fish scale is one of the major components of fish processing wastes and is often dumped along with other fish wastes (Ikoma et al., 2003). It is the part of a fish's integumentary system and produced from the mesoderm layer of the dermis which distinguishes them from reptile scales (Sharpe, 2001). The scales of bony fishes are derived entirely from the dermal layer of the skin and overlapped one another like the tiles (Mongera and Nüsslein-Volhard, 2013). There are various types of scales found in fishes depending on size, shape, and structure such as placoid, cycloid, ganoid, cosmoid, and ctenoid. Among these scales, placoid scales are found in cartilaginous fishes, while the rests are found in bony fishes (Lagler et al., 1977; Zhu et al., 2012). In general, the yield of scales is around $2 \%$ of fish body weight (Zall, 2008). This waste component has a range of potential applications including a natural adsorbent for heavy metal removal and coagulant for the recovery of proteins and pigments from wastewater. Fish scales consist of connective tissue protein, collagens, and calcium salts (Sankar et al., 2008). They are typically used to produce high valued collagens (Hsu et al., 2016; Huang et al., 2016; Mori et al., 2013), gelatins (Akagündüz et al., 2014), chitosan (Kumari et al., 2017), fish glue (Akter et al., 2017), etc. Moreover, some scales of fish (i.e., goldfish and zebrafish) living in a low-calcium environment have high potential value in regulating calcium level in plasma (Suzuki et al., 2016).

Bangladesh presently stands fifth in the world aquaculture production and has recorded an annual fish production of 4.38 million MT during 2018-2019 (DoF, 2019). Thus, every year a huge amount of fish wastes including fish scales are being generated. However, information regarding the marketing, processing and uses of fish scales in Bangladesh are scarce or little known.

Hitherto, no study has investigated the fate of fish scales generated in the Khulna region, Bangladesh. This region contributes a significant portion in annual fish production in inland water bodies, around $18.25 \%$ in $2018-2019$ (DoF, 2019). Therefore, the objective of this study was to determine the amount of fish scale produced from the local fish markets in Khulna, to characterize the channel of exporting fish scale in addition to the economic benefit, and to explore the potentialities of fish scale uses in Bangladesh. The findings would bring attention to different stakeholders and policymakers as it has a great potential to open a new business sector, can improve livelihood, and will earn foreign exchanges as well as increase national gross domestic product (GDP).

\section{MATERIALS AND METHODS}

The study was conducted in five major retail fish markets producing fish scales in the Khulna region from July 2018 to September 2018 namely Daulotpur, Chitraly, Sonadanga, Gollamary, and Shondha retail fish markets (Figure 1).

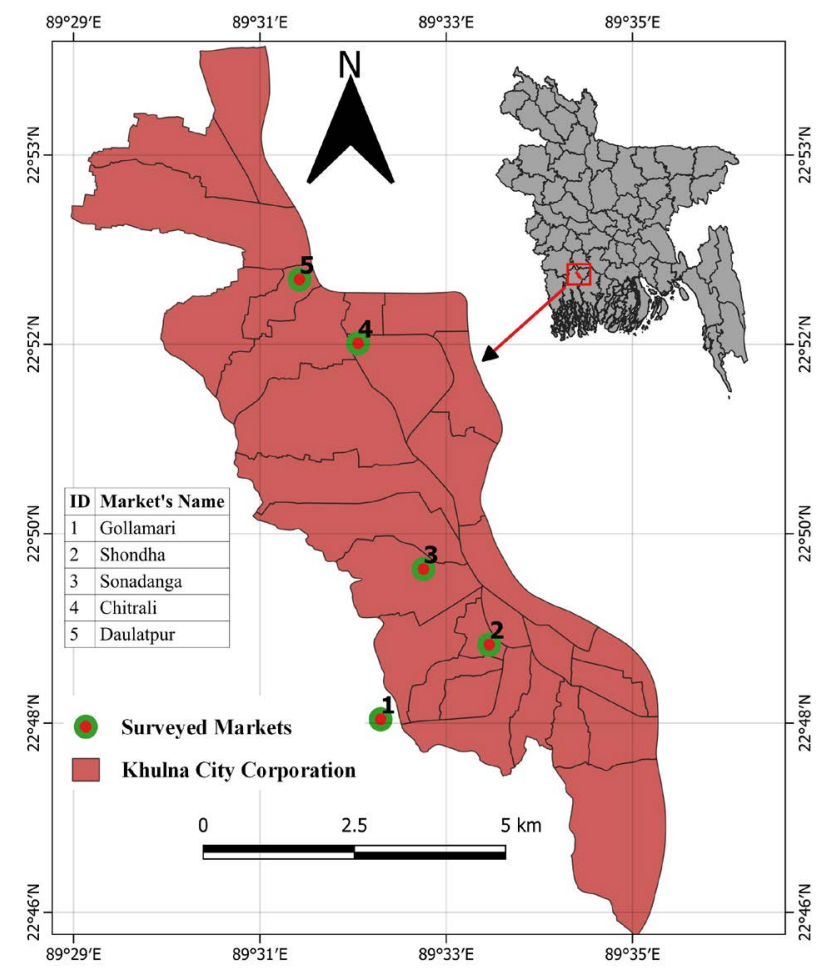

Figure 1: Map of surveyed markets in Khulna City Corporation, Khulna.

Primary data were collected through structured questionnaire surveys and discussions with different stakeholders. A primary survey was conducted using a draft questionnaire and then a final questionnaire was developed after making necessary adjustments. Questionnaire interviews on types of fish contributing to scale, the quantity of sell and market price and channel, were conducted with the fish scale retailers and fish processors. Secondary data were collected from different published articles, and the reports of both government and non-government organizations. The total number of actively participated interviewers in the survey was 25 . Key information was also taken from two informants from the renowned fish scale export industries in Bangladesh. Collected data were cross-checked and verified to eliminate errors and inconsistencies. Data were processed and finally analyzed using R-Studio.

\section{RESULTS AND DISCUSSION}

\section{FISH SCALE PRODUCTION}

Fish scale production (both raw and dry weight basis) in different markets was presented in Figure 2. In general, the fish scales become one third after drying. The amount 
of fish scales collected from each market varied with the size of market. The Shondha fish market was the biggest fish scales producer followed by the Chitraly, Daulatpur, Gollamari, and Sonadanga fish markets in Khulna. The average scale production from these five markets was 2.51 MT/year in raw weight basis and $0.824 \mathrm{MT} /$ year estimated in dry weight basis. In the present study, the total annual dry scale production in the studied markets was assessed as 4.15 MT. Sarker et al. (2009) reported that the total dry scale production in 2006 was 390 MT in the fish market of Dhaka metropolitan and they expected that this production would be $3380 \mathrm{MT}$ with considering 395 markets in Dhaka Metropolis, Bangladesh. The estimated total annual fish production from the species mentioned in Table 1 was 13,63,919 MT (DoF, 2019). In general, fish contains scales at a rate $2 \%$ of its body weight (Harikrishna et al., 2017). Therefore, it could be estimated that $0.02 \mathrm{~kg}$ (raw weight) fish scale can be obtained from $1 \mathrm{~kg}$ of fish, and the scale production calculated as $27,278 \mathrm{MT}(8,390 \mathrm{MT}$ on a dry weight basis) annually considering the fish species listed in Table 1. It was reported that Bangladesh exported around 2,500 MT fish scale (dry weight) per year (Islam, 2020), which is only around $30 \%$ of the total expected fish scale production. Therefore, it can be clearly understood that a huge amount of fish scale remains unutilized every year. According to the respondent, the majority portion (90\%) of the collected fish scale was exported to different countries around the world, while only $10 \%$ was used for local fish and poultry feed production.

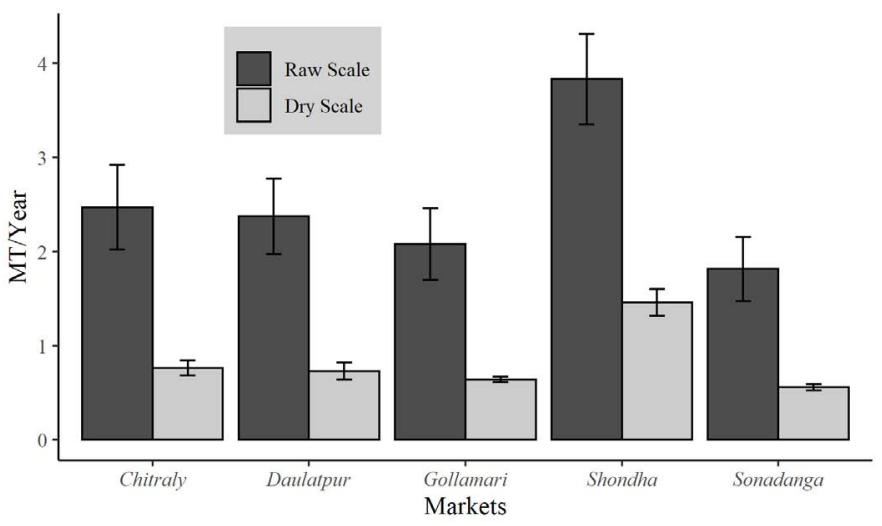

Figure 2: Amount of scale produced per year from five fish markets in Khulna city.

\section{CONTRIBUTING FISH SPECIES IN SCALE PRODUCTION}

A list of different fish species that contribute to the scale production has been given in Table 1. According to the respondents, 8 fish species contribute to generating fish scale in the study area. Carp fishes dominated in contributing the major production of fish scales because of their high market availability, value demand and larger scale size. The size of the fish scales bears a significant role in exporting trend. It was found that the higher the size, the higher the price. In general, small-size scales generated from fishes such as silver carp (Hypophthalmichthys molitrix) are not considered as an exporting product.

Table 1: List of fishes contributing to scales found in this study

\begin{tabular}{ll} 
Local name & Scientific name \\
\hline Rui & Labeo rohita \\
Catla & Catla catla \\
\hline Bhetki & Lates calcarifer \\
Mrigel & Cirrbinus cirrbosus \\
Koi & Anabas testudineus \\
Parshe & Mugil cephalus \\
Tilapia & Oreochromis niloticus \\
Bata & Labeo bata \\
\hline
\end{tabular}

Fish Cutter (Local market)

Removing scales, washing and sun drying

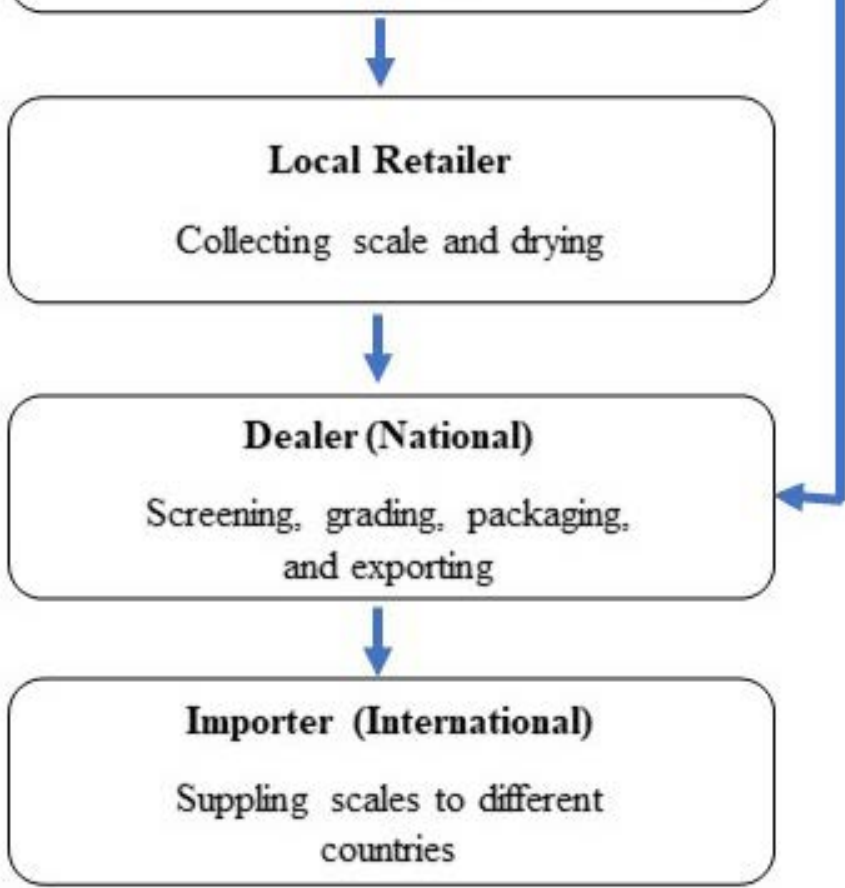

Figure 3: Marketing channel of fish scale in Bangladesh.

\section{FISH SCALE MARKETING CHANNEL}

The fish scale marketing channel in the study area was very simple. There were four major stakeholders namely fish cutter, retailer, dealer and importer involved in the fish scale marketing channel. The fish scale marketing channel and the roles of stakeholders engaged in this system were displayed in Figure 3.

The fish cutter was the first actor of this marketing channel who cuts fishes and removes scales in the respective fish market (Figure 4a). Then, the scales were washed with water and socked in Hydrochloric Acid for a while and sun dried 
(Figure 4b). After drying for at least two days, they become crispy. The fish cutter generally stored around 0.08-0.12 MT fish scales and who sold them to local retailers at a price of US\$0.24-0.29/kg depending on the size of scales. After collecting scales from the local markets, local retailers further dried them in the air and sold at a rate of US\$ $0.35-0.46 / \mathrm{kg}$ to the national dealers. Sarker et al. (2009) reported another stakeholder such as a secondary collector or tertiary collector to do the same task as a local retailer in Dhaka metropolitan. In some cases, the national dealers can directly collect scales from the fish cutters. After that, scales are stored in the warehouse of the national dealers and sorted out by screening or netting (Figure 4c) followed by packing in $25 \mathrm{~kg}$ each (Figure 4d). Scales are generally graded according to their size. However, scale traders or retailers opined that they did not use any specific unit to grade scale. Bamboo strainer is used to separate large sized scales (obtained from L. rohita, C. Catla, and other carp fishes) from smaller ones (A. testudineus, $M$. sephalus, $L$. bata etc.) (Figure 4c). Larger sized scales $(\approx 3 \mathrm{~cm})$ are packed for export at US\$ $0.71-0.91 / \mathrm{kg}$, whereas smaller sized, as well as lower quality scales, are sold to the local industries for manufacturing fish meal, artificial stones, etc. In support of this findings, Sarker et al. (2009) also reported that the secondary collectors supplied fish scales directly to fish or poultry feed manufacturing factories. The major fish scale exporting countries from Bangladesh are Japan, Hong-Kong, Singapore, Malaysia, Thailand, and China. Some Japanese companies indirectly import these scales after initial processing in China and Indonesia.

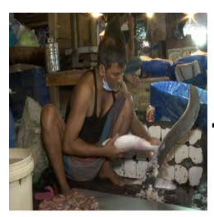

(a) Cutting

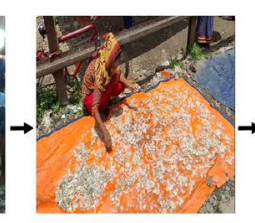

(b) Drying

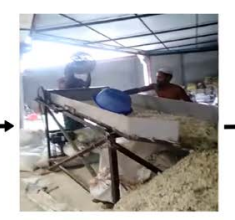

(c) Grading

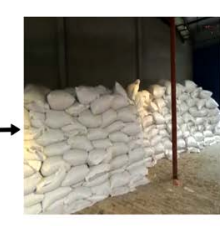

(d) Packaging
Figure 4: Fish scale processing steps in Bangladesh.

\section{PRICE OF FISH SCALE IN THE LOCAL MARKET}

The price of fish scale in the studied fish markets were ranging from 318 to 470 US\$/MT (in dry weight basis) (Table 2) with an average of 426 US\$/MT. The price of fish scales in the study area was also varied with its supply. According to the fish cutter, strong competition existed among the local retailers or traders to collect scale. Sometimes some local retailers offered comparatively higher prices of fish scales than the average offering price to collect a relatively large amount of scale from fish cutters or processors. About one decade earlier, Sarker et al. (2009) reported that the average price of dry scales in the market of Dhaka metropolitan was 290 US\$/MT. The above-mentioned data indicates that the fish scales price has been increased around $44 \%$ by the last one decade in Bangladesh.
Table 2: Price of fish scale in the different fish markets in Khulna city.

\begin{tabular}{|ll|} 
Name of Bazar & $\begin{array}{l}\text { Price of scale (US\$ } \\
\text { weight basis) }\end{array}$ \\
\hline Daulatpur Bazar & $450-472$ \\
\hline Chitraly Bazar & $465-470$ \\
\hline Sonadanga Bazar & $465-470$ \\
\hline Gollamari Bazar & $295-354$ \\
\hline Sondha Bazar & $354-472$ \\
\hline
\end{tabular}

Price OF FISH SCALES IN THE INTERNATIONAL MARKET Several organizations in Bangladesh export fish scales to different countries. The prominent fish scale exporting organizations, countries to export, and relative market prices are shown in Table 3. Most of these organizations are located in Khulna, Dhaka, and Chattogram. These organizations mostly collect dried scales, do grading and then pack to export. The average fish scales export from Khulna was around $63 \mathrm{MT} /$ month (range 41-123 MT/ month) in 2019-2020. Monthly fish scales export data from Khulna region is presented in Figure 5. Due to the COVID-19 pandemic fish scales were not exported in February, March and June 2020 (Source: Fish Inspection and Quality Control (FIQC), Khulna).

Table 3: Price of scale and organizations involved in international markets.

\begin{tabular}{lll}
$\begin{array}{l}\text { Organization } \\
\begin{array}{l}\text { Maximco } \\
\text { Khulna, Bangladesh }\end{array}\end{array}$ & Mapan & $\begin{array}{l}\text { Price (US \$/ } \\
\text { MT) }\end{array}$ \\
$\begin{array}{l}\text { Raka Enterprise } \\
\text { Khulna, Bangladesh }\end{array}$ & China & $527-2000$ \\
$\begin{array}{l}\text { Nahar Traders } \\
\text { Khulna, Bangladesh }\end{array}$ & China & $527-2000$ \\
$\begin{array}{l}\text { Orchid Trade Bangladesh } \\
\text { Chattogram, Bangladesh. }\end{array}$ & $\begin{array}{l}\text { South and } \\
\text { Southeast Asia, } \\
\text { Southern Europe }\end{array}$ & $1450-1500$ \\
$\begin{array}{l}\text { M/S Mamun Enterprise* } \\
\text { Dhaka, Bangladesh }\end{array}$ & $\begin{array}{l}\text { China and } \\
\text { South-Korea }\end{array}$ & $1200-1500$ \\
$\begin{array}{l}\text { Trade International } \\
\text { Chattogram, Bangladesh }\end{array}$ & $\begin{array}{l}\text { Hong-Kong, } \\
\text { Singapore, } \\
\text { Malaysia, Thailand, } \\
\text { and China. }\end{array}$ & \\
\hline
\end{tabular}

*Not active now.

\section{VERSATILE APPLICATION OF FISH SCALE}

Fish scales are generally considered as obsolete products in Bangladesh. The major portion of fish wastes including scales (85\%) was dumped as landfilling, while only $6 \%$ was found to be exported and the rest (9\%) was used in fish and poultry feed industries (Sarker et al., 2009). The fish scales have been used for various purposes in different countries 
of the world. The multiple applications of the fish scales are given in Table 4. Due to the versatile uses of fish scales, processing and generation of its derivatives in Bangladesh can be recognized as a potential economic sector.

\section{INSTITUTIONAL INVOLVEMENT}

At present, there are three key institutions, which are involved in regulatory and financial activities in the fish scales business. The institutions involved in fish scales business and their key contributions are given in Table 5 . Although fish scales export is a promising sector in the economy of Bangladesh, it remains almost unknown to most of the institutions. As a result, the involvement of the institution is not very much functional. In general, banks defer loans for investing money in this sector.

Table 4: Multiple applications of fish scale in the world.

Use Details

Collagen/ Extracted collagen may serve as a captivating alternative to mammalian collagen collagen peptide and can be exploited in food, biomedical as well as in pharmaceutical fields.

Hydroxyapatite Hydroxyapatite helps to develop scaffold bone. So, it can be a suitable biomaterial Deb et al. (2019) for orthopedic treatment.

Thermochemical Fish scales have thermal behavior to propose the application of this biomass feedstock as an alternative energy source for clean energy generation with low pollutants emission.

Environmental Fish scales can be used as environmental, bioindicators to evaluate potential risk Viana et al. (2019) monitoring for the ichthyofauna and, consequently, for humans.

Efficient filler Fish scale waste can be transformed into a highly effective filler for starch foam, which holds promise for the application of recycled waste from the seafood industry to produce environmentally friendly products.

Agricultural Fish scales can be used as a potential resource for agricultural applications by em- Santana et al. (2019) practice ploying solubilizing phosphate bacteria.

Chitin, chitosan Transforming chitin into chitosan is used in the chemical wastewater treatment

Kumari and Rath (2014) and food industry for food formulation as binding, gelling, thickening, and stabilizing agent. Chitosan has multiple applications for biomedicine, dietary supplements, and agriculture, for example. It has properties that help to prevent blood clots and protect plant seeds, to name a few examples. The most extreme applications include using chitosan as a repairing material for car paint coatings.

Glue Very good looking, attractive colored, and appealing flavored fish glue was prepared from tilapia fish scale.

Heavy metal remover Fish scales can be used as an adsorption material to remove heavy metals from water such Cd (II), Pb (II), Cu (II), Fe (III), Cr (III), Zn (II), As (III), Co (III), $\mathrm{Mn}$ (II), and Ni

Silva, Torquato and Cruz (2019)

Chiarathanakrit, Riyajan and Kaewtatip (2018)

Akter et al. (2017)

Mustafiz et al., (2003); E1Sheikh and Sweileh (2008); Prabu, Shankarlal and Natarajan (2012)

Bio Cornea The fish scale-derived Bio Cornea can seal full-thickness corneal perforation and Chen et al. (2015) stabilize the integrity of ocular anterior chamber.

Anticancer Guanine is found in the cells protoplast of fish scale and can synthesize 6-TG property that has the effective anticancer property.

Suo-Lian, Huai-Bin and Dong-Jiao (2017)

Table 5: List of the key institutions involved in fish scale trading.

$\begin{array}{ll}\begin{array}{l}\text { Name of the institutions } \\ \text { Ministry of commerce }\end{array} & \begin{array}{l}\text { Functions } \\ \text { The Ministry of Commerce is responsible to approve the trade license and Export Registration } \\ \text { Certificate among the fish scale businessmen. }\end{array} \\ \text { Banks } & \begin{array}{l}\text { Banks provide loans to the fish scale businessmen with the same condition as for General Trading } \\ \text { Business. Banks are also responsible for money transactions between international importers to the } \\ \text { national dealer. }\end{array} \\ \begin{array}{l}\text { Fish Inspection and } \\ \text { Quality Control (FIQC) }\end{array} & \begin{array}{l}\text { After being prepared for export, the Fish Inspection and Quality Control (FIQC) unit of the } \\ \text { Ministry of Fisheries and Livestock visits the fish scale warehouse and collect samples to test the } \\ \text { quality. Export is allowed only after getting an approval certificate from FIQC with conforming that } \\ \text { moisture content of dried scales should be below 15\%. }\end{array}\end{array}$




\section{IMPACT OF COVID-19}

Like other businesses, COVID-19 has caused a serious impact on fish scales export from Bangladesh. Before this pandemic, fish scales were sold at US\$ 1.42-1.54/ $\mathrm{kg}$, whereas now the price is reduced significantly to US\$ $0.30-0.35 / \mathrm{kg}$. Moreover, due to this pandemic situation, the export of fish scales has been stopped for a few months in the last year (Figure 5). According to the traders, a Japanese company which controls the trade of these products all over the world was interested to make a contract with them to establish a factory in Bangladesh (Islam, 2020). Unfortunately, this initiative has been delayed due to COVID-19 pandemic.

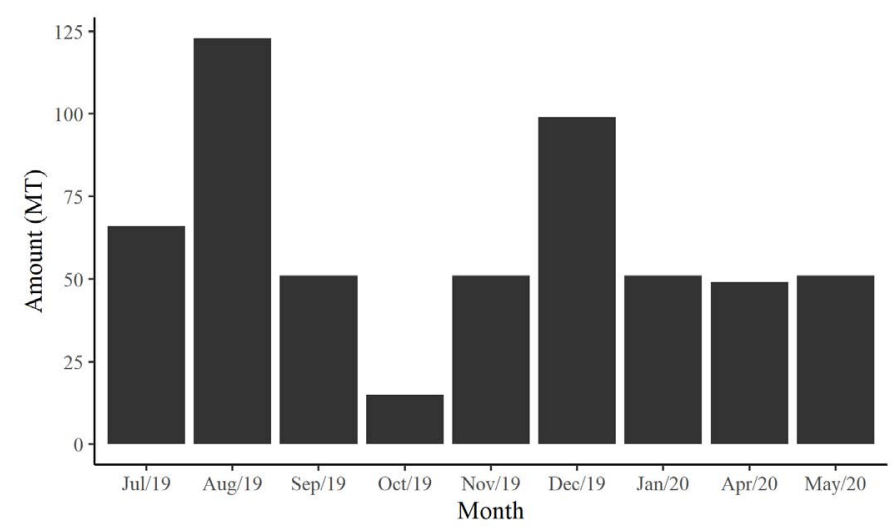

Figure 5: Status of fish scale export from Khulna region in 2019-2020.

\section{CONCLUSION AND RECOMMENDATIONS}

Fish scale business is one of the potentials as well as promising sectors in Bangladesh. The current yield of the fish scale in Khulna was around 4.15 MT and the total yield could be increased several folds by collecting scales from all sources (e.g., houses, hotels etc.) including the markets. The market channel of fish scales in the Khulna region flows through the fish cutters, local scale retailers, national dealers. The major part of the collected scales is being exported in different countries, while a small part is used in Bangladesh for poultry and fish feed, preparation. Since the fish scale has versatile uses in different countries, the diversified applications of fish scales can be expanded in Bangladesh as well. Therefore, in addition to earning foreign exchange, this industry can play a significant role in creating employment, improving livelihood, increasing environmental sustainability and contributing to the national economy.

A detailed study is required to characterize the quality of available fish scales and to address the feasibility of its diversified commercial production in Bangladesh. Initiatives should be taken to collect maximum fish scales produced in the country following different strategies.
Campaign for public awareness could be an effective strategy in this regard. I addition, a direct marketing link between the local fish cutters and the national dealers can be established for higher margin of primary stakeholders. Fish scales processing factories can be set up to raise local uses. The government and associated agencies should also come forward to promote this business.

\section{NOVELTY STATEMENT}

This study investigates the production, market chain, and future potential of fish scales in Bangladesh following primary and secondary data.

\section{AUTHOR'S CONTRIBUTION}

Muhammad Abdur Rouf: Conceptualization, Methodology, Writing-review and editing, Supervision, Md Rony Golder: Methodology, Data curation, visualization, writing original draft; Naima Ahmed Kana: Methodology; data collection, writing original draft; Sudip Debnath: Writing orginial draft, Writing-review and editing, Md. Moshiur Rahman: Writing-review and editing; Roshmon Thomas Mathew: Writing-review and editing; Yousof Naser Alrashada: Writing-review and editing.

\section{CONFLICT OF INTEREST}

The authors have declared no conflict of interest.

\section{REFERENCES}

-Akagündüz Y, Mosquera M, Giménez B, Alemán A, Montero P, Gómez-Guillén MC (2014). Sea bream bones and scales as a source of gelatin and ACE inhibitory peptides. LWTFood Sci. Technol., 55: 579-585. https://doi.org/10.1016/j. lwt.2013.10.026

-Akter S, Rahman MA, Naher J, Wahidur M, Majumder R, Alam AKMN (2017). Fish glue from tilapia scale and skin and its physical and chemical characters. Int. J. Fish Aquat. Sci., 5: 255-257.

- Chakraborty R, Bepari S, Banerjee A (2011). Application of calcined waste fish (Labeo rohita) scale as low-cost heterogeneous catalyst for biodiesel synthesis. Bioresour. Technol., 102: 3610-3618. https://doi.org/10.1016/j. biortech.2010.10.123

- DoF (2019). Yearbook of fisheries statistics of Bangladesh. Fisheries resources survey system, department of fisheries (DoF). Ministry of Fisheries and Livestock, Dhaka, Bangladesh.

- Harikrishna N, Mahalakshmi S, Kiran KK, Reddy G (2017). Fish scales as potential substrate for production of alkaline protease and amino acid rich aqua hydrolyzate by bacillus altitudinis GVC11. Indian J. Microbiol., 57: 339-343. https://doi.org/10.1007/s12088-017-0664-2

- Hsu HH, Uemura T, Yamaguchi I, Ikoma T, Tanaka J (2016). Chondrogenic differentiation of human mesenchymal stem cells on fish scale collagen. J. Biosci. Bioeng., 122: 219-225. 
https://doi.org/10.1016/j.jbiosc.2016.01.001

-Huang CY, Kuo JM, Wu SJ, Tsai HT (2016). Isolation and characterization of fish scale collagen from tilapia (Oreochromis sp.) by a novel extrusion-hydro-extraction process. Food Chem., 190: 997-1006. https://doi. org/10.1016/j.foodchem.2015.06.066

-Ikoma T, Kobayashi H, Tanaka J, Walsh D, Mann S (2003). Physical properties of type I collagen extracted from fish scales of Pagrus major and Oreochromis niloticas. Int. J. Biol. Macromol., 32: 199-204. https://doi.org/10.1016/S01418130(03)00054-0

-Islam F (2020). Fish scale is also an export product [WWW Document]. Prothom Alo. URL https://www.prothomalo. com/business/(accessed 7.27.21).

-Kittiphattanabawon P, Benjakul S, Visessanguan W, Nagai T, Tanaka M (2005). Characterisation of acid-soluble collagen from skin and bone of bigeye snapper (Priacanthus tayenus). Food Chem., 89: 363-372. https://doi.org/10.1016/j. foodchem.2004.02.042

- Kumari S, Kumar ASH, Abanti S, Kumar RP (2017). Physicochemical properties and characterization of chitosan synthesized from fish scales, crab and shrimp shells. Int. J. Biol. Macromol., 104: 1697-1705. https://doi. org/10.1016/j.ijbiomac.2017.04.119

-Lagler KF, Bardach JE, Miller RR, Passino DRM (1977). Ichthyology, $2^{\text {nd }}$ Edition. John Willey and Sons. Inc. New York. London. Sydney. https://doi.org/10.2307/1443299

- Lopes C, Antelo LT, Franco-Uría A, Alonso AA, Pérez-Martín R (2015). Valorisation of fish by-products against waste management treatments. Comparison of environmental impacts. Waste Manage., 46: 103-112. https://doi. org/10.1016/j.wasman.2015.08.017

- Mongera A, Nüsslein-Volhard C (2013). Scales of fish arise from mesoderm. Curr. Biol., 23: R338-R339. https://doi. org/10.1016/j.cub.2013.02.056

- Mori H, Tone Y, Shimizu K, Zikihara K, Tokutomi S, Ida T, Ihara H, Hara M (2013). Studies on fish scale collagen of Pacific saury (Cololabis saira). Mater. Sci. Eng., C33: 174-
181. https://doi.org/10.1016/j.msec.2012.08.025

- Nagai T, Suzuki N (2000). Isolation of collagen from fish waste material. Skin, bone and fins. Food Chem., 68: 277-281. https://doi.org/10.1016/S0308-8146(99)00188-0

- Sankar S, Sekar S, Mohan R, Rani S, Sundaraseelan J, Sastry TP (2008). Preparation and partial characterization of collagen sheet from fish (Lates calcarifer) scales. Int.J. Biol. Macromol., 42: 6-9. https://doi.org/10.1016/j.ijbiomac.2007.08.003

- Santana CA, Piccirillo C, Pereira SIA, Pullar RC, Lima SM, Castro PML (2019). Employment of phosphate solubilising bacteria on fish scales - Turning food waste into an available phosphorus source. J. Environ. Chem. Eng., 7: 103403. https://doi.org/10.1016/j.jece.2019.103403

- Sarker BS, Hasan M, Rahman MS, Rahman AFMA (2009). Non-conventional Fishery By-products of Fish Markets in Dhaka Metropolis, Bangladesh. Asia Pac. J. Rural Dev., 19: 57-72.https://doi.org/10.1177/1018529120090205

- Sharpe PT (2001). Fish scale development: Hair today, teeth and scales yesterday? Curr. Biol., 11: R751-R752. https:// doi.org/10.1016/S0960-9822(01)00438-9

- Suzuki N, Kitamura K, Hattori A (2016). Fish scale is a suitable model for analyzing determinants of skeletal fragility in type 2 diabetes. Endocrine, 54: 575-577. https://doi. org/10.1007/s12020-016-1153-9

-Wu CJ, Chai HJ, Li JH, Huang HN, Li TL, Chan YL, Shiau CY (2010). Effects of sizes and conformations of fish-scale Collagen peptides on facial skin qualities and transdermal penetration efficiency. J. Biomed. Biotechnol., 2010: 1-9. https://doi.org/10.1155/2010/757301

- Zall RR (2008). Unconventional techniques to deal with waste recovery or treatment schemes., In: Managing Food Industry Waste. Blackwell Publishing, pp. 105-126. https:// doi.org/10.1002/9780470752531.ch11

-Zhu D, Ortega CF, Motamedi R, Szewciw L, Vernerey F, Barthelat F (2012). Structure and mechanical performance of a "modern" fish scale. Adv. Eng. Mater., 14: B185-B194. https://doi.org/10.1002/adem.201180057 